building projects 55 per cent was for science and applied science buildings, 5 per cent for libraries, and 20 per cent for student residences.

In the chapter on university expansion the Committee details the considerations which led to the conscious planning of expansion from 80,600 places in 1953-54 to 70,000 in $1973-74$ and then the considerations which influence its views on the size and location of universities. It believes that many of the university institutions in Britain are still too small to be academically or economically viable, and that the weight of argument generally is in favour of larger institutions. Growth in the number of subjects and in their coverage as well as the increasing responsibilities of the universities in the search for new knowledge led to greater specialization and greater size, while tho increasing costliness of research through the need for expensive equipment and extensive library provision necessitates maximum utilization of resources and some degree of concentration in thoir availability. The universities are in fact already becoming bigger, and whilo the major part of the increase between $1953-54$ and 1966 67 will be found in the English eivic universities, the further planned expansion of 20,000 places by 1973-74 will take place almost entirely in the civic universitiesthe seven now universities providing about 14,000. By the end of the present quinquennium in 1966-67, the faculties of pure and applied science will contain $46 \cdot 6$ per cent of the students, arts and social studies 39.3 per cent and medicine and dentistry $11 \cdot 6$ per cent. The outstanding increase in the proportion of students studying pure and applied science is due essentially to a relative stability in the numbers studying medicine, dentistry, agriculture and veterinary science.

The Committee believes that the time is right for further consideration of the postgraduate degree structure. In commenting that the coming expansion will necessitato the broadening of undergraduate education, it refers to the need for more fundamental thinking on the purposes of university education, the qualities of mind it should develop, and whether these are fostered sufficiently by the courses offered and the kind of life the student lives. On the basis of costs in 1961-62, it estimates the capital cost of expansion as being about $\mathfrak{£ 1 , 2 0 0}$ for an additional place in arts, $£ 2,400$ in science and $£ 3,500$ in applied science. The total capital cost per student place of a conventional hall of residence at an existing university is put at about $£ 1,800-£ 1,850$; alternatives are being explored such as the provision of student flats which could bring the figure to below $£ 1,500$. Conversion to student use of suitably large houses in the vicinity of a university offers a possibility of meoting a substantial proportion of the need at about $£ 600$ a head. To provido residontial accommodation for about two-thirds of the increase to 70,000 students by the early 1970's would increase the per capita cost by about $£ 1,000$ to a total figure of about

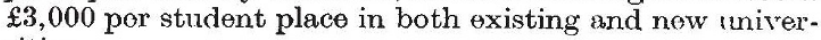
sities.

The chapter on the new universities gives a concise account of the various proposals and first steps for now universities, the pattern of their development, including the factors which determined their location, the academic planning boards and thoir terms of reforence and the new linos of development in univorsity government, coverage, academic advisory committees and experiments in breadth of curricula, student organization and residence and in teaching methods. A chapter on the growth and control of capital expenditure covers the various points which have been at issue with the Public Accounts Committee or the Estimates Committee and which were investigated by the Gater Committee and Sir Arthur Rucker. The University Grants Committee emphasizes that for the effective and oconomic execution of building programmes close and continuous consultation between the universities' officers, including, subject to the university's agreement, their professional advisers and the Committeo's officers, is essontial. Except with minor works, no commitment should be enterod into for which grant-in-aid is to be sought without prior approval by the University Grants Committee, and once its approval has beon given to a particular proposal or a building schedule, no change should be made which might increaso the amount for which grant-in-aid is sought without the Committoo's agreement. The Committee is not prepared to recommend for grant expenditure which has not been agreed by it in advance. There is also some discussion of the division of responsibility between the Committee and the Research Councils for the provision of research equipment, but generally the assessor system has worked well. In a chapter on academic salaries and staffing, the Committee comments that over the years the proportion of academic recruits with first-class degrees has declined, as has the overall proportion of firsts among graduates. It points out that changes in the post-war years suggest that the first need is improvement in salaries and career prospects if standards of teaching and research are not to be allowed to continue to decline. Even greater improvement will be needed if further expansion is to be achieved without a yet groater fall in standards.

\title{
TECHNOLOGY AND THE SIXTH FORM IN SCHOOLS
}

A CONFERENCE, organized by the British Petroleum Co., Ltd., was held in London during February 29 March 1 under the chairmanship of Mr. A. D. C. Poterson, at which school, university and technical college teachers considered the implications of the Oxford report on Technology and the Sixih Frorm Boy (soe Nature, 199, 958 (1963); 200, 219 (1963)).

Discussion hinged on four main issues-the 'image' of the technologist, the transition between pure and applied science, the transition from school to college and university and the possibility of teachers adding to their professional skills by gaining appropriate experience within industry.

In considering the 'image' of the technologist in Britain, the conference emphasized the need to correct the nebulous impression of the technologist, held by the public (and especially by parents), by boys and girls and by teachers. Possible lines of action were the production of good technical films, the organization of public loctures by enthusiasts (to be given before a student entered the sixth form), more works visits with an emphasis on the jolss that are done, a broadening of the activities of the Institutes of Education to include visits, technological lectures and vacation attachments, the introduction into schools of minor projects, further development in the visiting of colleges of advanced technology and universities and the employment of technologists as staff and visiting staff.

To help the transition between pure and applied science, various suggestions were made. The principles of pure science could bo illustrated from applied science and, to help, mobile laboratories should bo made available together with films that were more appropriate than the rather elementary ones at presont available. Some adjustment of the science syllabus would also contribute and, again, the 'image' of technology needed correction if pupils and teachers were to develop a greater awaroness of the relationship between the two areas.

As for the actual teaching of technological material, the conference felt that this should spring from daily teaching - ongineering drawing, for example, should arise from studios in geometry at the Ordinary Level of the General 
Certificate of Education, and at the Advanced Level consideration should be given to the possibility of including a practical thesis. Closer links between school laboratories and workshops needed to be developed; here the experience of Bryanston School and of some Middlesex schools which had developed applied science laboratories had valuablo lessons. But it was emphasized that the transition between pure and applied science should be encouraged at overy stage of education and experience - there was general agreement that it would be disastrous if all those employed in technology had been trained as technologists.

The transition from school to university was obviously a key moment in the general problem. A boy might have made his decision by the time he entered tho lower sixth form and advice often came (quite rightly) from the science master. But was there any case for full-time careers masters on the American pattorn ? Overlap in work between sixth form and university might be a good thing so far as consolidation was concernod, but could also come as an anti-climax-here was a need for more liaison between school teachers and university teachers. As for the choice between colleges of advanced technology and university, this often decided itself. Sometimes there were technicalities such as the need for language qualification, sometimes special courses made their own appeal. But at university could the idea of a common first year be extended so that flexibility of choice in specialization remained?

It was generally agreed that the good teacher is a better teacher for having had some experience outside his teach. ing job. But the question of what a teacher should do in industry was not simple - he had to get the 'feel' of industry and this could not be done by standing and watching. Instead, he needed to take some live part in an industrial project and, although it was difficult to organize such experience on a large scale, it was something to be encouraged.
In summing up the conference, Mr. Peterson highlighted the points that had emerged or had been confirmed. The 'image' of applied science was unsatisfactory : the teaching of science in school could be enlivened by directing atten tion to the problem-solving aspects of applied science and to its position as a bridge between the work of the pure scientist and human welfare. A great deal of experimont was also needed in teaching methods with an emphasis on the question of problem solving. How practicable was it and could it engender gaps in knowledge that might hinder the transition from pure science to tochnology and vice versa?

Industry could help in suggesting experiments and illustrations, but, above all, it could help teachers to go into industry to look for their own illustrations. A working party of dons and teachers was necessary to consider the question of overlap between school and university curriculum; lecturos by outstanding men could be filmed. Finally, there was a need for financial assistance for the technologist who wanted to switch to teaching and neoded help before he could embark on a year's diploma in education.

In winding up the conferenco, Mr. H. S. Mullaly, staff manager of British Petroleum, said that visits could be arranged, though these should be for a specific purpose and not an undirectod 'look around'. As for industry releasing men to teach, this was not a simple issue, but some developments were possiblo. There were directions in which industry could help, but it was reluctant to add to the careers and recruiting pressure on the schools and the initiative in following up these various ideas should, therefore, come from the schools. A first step would be to sot up a working party between British Petroleum and the Association for Science Education to consider the detailod implications of the various recommendations that had been mado.

\title{
PLANT INTRODUCTION IN ASIA AND AUSTRALIA
}

\author{
BY DR. DAVID B. PARBERY \\ Division of Land Research and Regional Survey, Kimberley Research Station, Kununurra, Western Australia
}

\begin{abstract}
A THREE hundred and forty-seven page report has been submitted to the Cultural Affairs Office of the South-east Asia Treaty Organization, Bangkok, dealing with "Plant Introduction as an Economic Aid in the Agricultural Development of Asia and Australia". This is a research project financed by a grant under the Southeast Asia Treaty Organization programme sponsoring scientific research in the underdeveloped countries within the defence zone. The grant covered travel and general expenses over four months in Malaya, Australia, Thailand, Burma, India, Pakistan and Ceylon. The following is a brief review of the report.

Australian agriculture is based entirely on cultivated plants which have been introduced from other countries. The role of plant introduction during Australia's history has been one of outstanding success, beginning with the earliest settlers in the eighteenth century. To quote Hartley", "Australia is unique among continental areas in the complete absence in the indigenous vegetation of species which have been brought into cultivation as crop plants".

It was not until the C.S.I.R.O. Division of Plant Industry was formed in 1929 that plant introduction to Australia was placed under centralized control with the creation of a Section of Plant Introduction within the Division. From then until the present time, introductions of agricultural plants in excess of thirty thousand ${ }^{2}$ have been received by the Section. The majority of these introductions have been applied to the temperate and sub-
\end{abstract}

tropical zones. However, during recent years, interest in Australian agricultural development has shifted from the temperate south to the tropical north. Relatively few introductions have been received, particularly of pasture legumes, which have proved successful in this more rigorous environment. As a result, during the past decade, Australian agricultural scientists have become more and more interested in the introductions from tropical areas.

The Plant Introduction Section of C.S.I.R.O. was responsible for organizing expeditions to eastern and subtropical South America, as well as tropical Africa and South Africa, between 1947 and 1953. The first organized collections of tropical species for testing in Australia were made at these times. Following the success of these explorations, interest moved to tropical Asia. It was realized that both cultivated and wild species of plants, throughout this vast region, could be of prime importance in the further agricultural development of Australia's tropical north. At the same time, considering the general success of plant introduction in Australia as well as efforts being made to elevate standards of living in many of the Asian countries through advance in the rural industries, it was thought that Australia could contribute significantly to their economies by making available to these countries seed of tested cultivars for trial in agricultural development programmes.

Australia's agricultural development was, and is, hindered by the presence of extensive soil bodies low in natural phosphate and nitrogen reserves. While the 